\title{
Iron(II)-Catalyzed Oxidation of Arsenic(III) in a Sediment Column
}

\section{Supporting Information}

\author{
Kevin J. Bisceglia ${ }^{\dagger}$, Kevin J. Rader ${ }^{\dagger \dagger}$, Richard F. Carbonaro ${ }^{\ddagger}$, Kevin J. Farley ${ }^{\ddagger}$, \\ John D. Mahony ${ }^{\ddagger}$, and Dominic M. Di Toro ${ }^{\dagger \dagger}, \frac{+\neq}{*} *$
}

$\dagger$ Department of Geography and Environmental Engineering, Johns Hopkins University, Baltimore, Maryland 21218

${ }^{\dagger}$ Department of Civil and Environmental Engineering, University of Delaware, Newark Delaware, 19716

‡ivil and Environmental Engineering Department, Manhattan College, Manhattan College Parkway, 10471

\$ HydroQual, 1200 MacArthur Boulevard, Mahwah, NJ 07430

Number of Pages: 15

Number of Figures: 3

Number of Tables: 4

*Corresponding author. Tel.: (302) 831-4092, Fax: (302) 831-3640. E-mail: dditoro@ ce.udel.edu 


\section{Proposed Mechanism}

Figure S1 is a graphical representation of the mechanism proposed by Hug and Leupin (1).

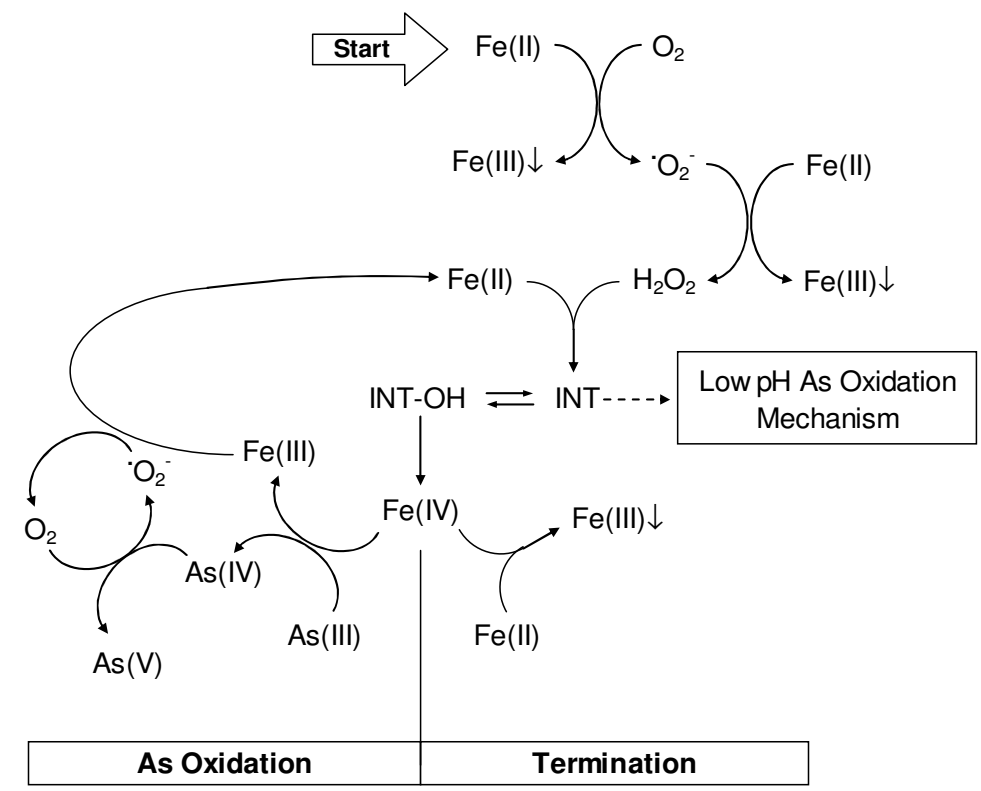

Figure S1. Arsenic(III) oxidation mechanism for circumneutral $\mathrm{pH}$ systems (1).

\section{TICKET Equilibrium and Kinetic Reactions}

The Tableau Input Coupled Kinetic Equilibrium Transport (TICKET) model (2) provides for the simultaneous solution of chemical equilibrium, kinetic, and transport processes and is similar in capability to the reactive transport model PHREEQC (version 2.8) (3). PHREEQC calculates chemical interaction separately from transport in a split-operator scheme and uses a Runge-Kutta algorithm (up to $6^{\text {th }}$ order) to evaluate chemical kinetics. TICKET uses a fully implicit numerical integration scheme that is better suited for modeling the fast kinetics involving radical intermediates in the Fe(II)-catalyzed As(III) oxidation pathway. 
TABLE S1. Equilibrium and Kinetic Parameters

Equilibrium Reactions

A. $\mathrm{Fe}^{2+}+\mathrm{H}_{2} \mathrm{O} \leftrightarrow \mathrm{FeOH}^{+}+\mathrm{H}^{+}$

B. $\mathrm{Fe}^{3+}+\mathrm{H}_{2} \mathrm{O} \leftrightarrow \mathrm{FeOH}^{2+}+\mathrm{H}^{+}$

C. $\mathrm{Fe}^{3+}+2 \mathrm{H}_{2} \mathrm{O} \leftrightarrow \mathrm{Fe}(\mathrm{OH})_{2}{ }^{+}+2 \mathrm{H}^{+}$

D. $\mathrm{Fe}^{3+}+3 \mathrm{H}_{2} \mathrm{O} \leftrightarrow \mathrm{Fe}(\mathrm{OH})_{3}{ }^{0}+3 \mathrm{H}^{+}$

E. $\mathrm{INT}-\mathrm{OH}+\mathrm{H}^{+} \leftrightarrow \mathrm{INT}+\mathrm{H}_{2} \mathrm{O}$

\section{Kinetic Reactions}

A. $\mathrm{As}(\mathrm{IV})+\mathrm{O}_{2} \rightarrow \mathrm{As}(\mathrm{V})+\mathrm{O}_{2} \bullet^{-}$

B. $\mathrm{Fe}^{2+}+\mathrm{O}_{2} \rightarrow \mathrm{Fe}^{3+}+\mathrm{O}_{2}^{\bullet}$

C. $\mathrm{Fe}^{2+}+\mathrm{O}_{2} \bullet^{-}+2 \mathrm{H}^{+} \rightarrow \mathrm{Fe}^{3+}+\mathrm{H}_{2} \mathrm{O}_{2}$

D. $\mathrm{Fe}^{2+}+\mathrm{H}_{2} \mathrm{O}_{2} \rightarrow$ INT

E. $\mathrm{FeOH}^{+}+\mathrm{H}_{2} \mathrm{O}_{2} \rightarrow \mathrm{INT}-\mathrm{OH}$

F. INT-OH $\rightarrow \mathrm{Fe}(\mathrm{IV})$

G. $\mathrm{Fe}(\mathrm{IV})+\mathrm{Fe}^{2+} \rightarrow \mathrm{Fe}^{3+}+\mathrm{Fe}^{3+}$

H. $\mathrm{Fe}(\mathrm{IV})+\mathrm{FeOH}^{+} \rightarrow \mathrm{Fe}^{3+}+\mathrm{Fe}^{3+}$

I. $\mathrm{As}(\mathrm{III})+\mathrm{Fe}(\mathrm{IV}) \rightarrow \mathrm{As}(\mathrm{IV})+\mathrm{Fe}^{3+}$

J. $\mathrm{Fe}^{3+}+\mathrm{O}_{2} \bullet^{-} \rightarrow \mathrm{Fe}^{2+}+\mathrm{O}_{2}$

K. $\mathrm{FeOH}^{2+}+\mathrm{O}_{2} \bullet^{-} \rightarrow \mathrm{Fe}^{2+}+\mathrm{O}_{2}+\mathrm{OH}$

L. $\quad \mathrm{Fe}(\mathrm{OH})_{2}^{+}+\mathrm{O}_{2} \bullet^{-} \rightarrow \mathrm{Fe}^{2+}+\mathrm{O}_{2}+2 \mathrm{OH}^{-}$

M. $\mathrm{Fe}(\mathrm{OH})_{3}{ }^{0}+\mathrm{Fe}(\mathrm{OH})_{3}{ }^{0} \rightarrow$ precip + iprecip

N. $\mathrm{Fe}(\mathrm{OH})_{3}{ }^{0}+$ precip $\rightarrow$ precip + iprecip $\log K$

$-9.51$

$-13.8$

5.24

$\log k, \mathrm{M}^{-1} \mathrm{~d}^{-1}$ or $\mathrm{d}^{-1}$

13.98

$7.67^{\mathrm{a}}$

11.94

6.37

12.06

10.94

8.22

\section{Adsorption Reactions}

A. $\quad$ As(III $)+$ Sand $\leftrightarrow$ As $($ III $) \equiv$ Sand

$\log K$

$-2.87^{\mathrm{b}}$

B. $\mathrm{Fe}^{2+}+\mathrm{Sand} \leftrightarrow \mathrm{Fe} \equiv$ Sand

$-1.49^{\mathrm{b}}$

C. $\mathrm{As}(\mathrm{III})+\left(1,7.85^{\mathrm{c}}\right) \mathrm{HFO} \leftrightarrow \mathrm{As}(\mathrm{III}) \equiv(\mathrm{HFO})_{7.85}$

$4.57^{\mathrm{c}}$

D. $\mathrm{As}(\mathrm{V})+\left(1,23.5^{\mathrm{c}}\right) \mathrm{HFO} \leftrightarrow \mathrm{As}(\mathrm{V}) \equiv(\mathrm{HFO})_{23.5}$

$5.15^{\mathrm{c}}$

Unless otherwise noted, constant are taken from Hug and Leupin (1). Species in italics are written to balance the equations but are not included in the model. ${ }^{\mathrm{a}}$ Calculated from Millero et al. (6). ${ }^{b}$ Calibrated. ${ }^{\mathrm{c}}$ Estimated from Dixit and Hering (4). Note: HFO = Hydrous Ferric Oxide. First number in parentheses refers to the exponent to which the component is raised in the mass action law. The second number is the stoichiometric coefficient of the species in the component mass balance equation.

Table S1 contains all equilibrium and kinetic reactions found in the TICKET model. The equilibrium reaction set of Hug and Leupin (1) has been expanded to include adsorption of iron and arsenic to sand and adsorption of arsenic to precipitated iron(III) oxides (Table S1, 
Adsorption Reactions). The equilibrium constants for $\mathrm{Fe}(\mathrm{II})$ and $\mathrm{As}(\mathrm{III})$ adsorption to sand (Adsorption Reactions A and B) are calibrated to the data. Adsorption of arsenic to precipitated iron(III) oxides (Adsorption Reactions C and D) is described using Dixit and Hering's (4) parameterization of Dzombak's surface complexation model (5). It is assumed that precipitated iron(III) solids in the experimental column can be modeled as hydrous ferric oxides (HFO). A description of how the surface complexation model was implemented in TICKET can be found below.

The kinetic reactions from Hug and Leupin (1) are used with minimal alteration (Table S1). The reactions are treated as elementary steps. The rate expressions can be derived accordingly. The rate of Kinetic Reaction B (Table S1) was adjusted using the pH dependency relation described in Millero et al. (6). All other rates are unchanged. Reactions pertaining to low $\mathrm{pH}$ As(III) oxidation are omitted because the experiments were performed at $\mathrm{pH} 8.3$. Kinetic and equilibrium reactions involving (bi)carbonate were also omitted because the carbonate concentrations were small.

The precipitation of Fe(III) is modeled, following Hug and Leupin (1), as a set of kinetic reactions (Table S1, Kinetic Reactions M and N). An additional component, “iprecip", is added as a reaction product since the concentration of $\mathrm{Fe}(\mathrm{III})$ solid is needed to formulate equilibrium adsorption reactions. This does not alter the kinetics of Fe(III) precipitation. The interpretation of "precip" and "iprecip" is as follows. Two $\mathrm{Fe}(\mathrm{OH})_{3}{ }^{0}$ combine to form an outer or surface $\mathrm{Fe}(\mathrm{III})$ precipitate ("precip") and an inner $\mathrm{Fe}(\mathrm{III})$ precipitate ("iprecip"). The $\mathrm{Fe}(\mathrm{OH})_{3}{ }^{0}$ species can then react with the surface precipitate to form more surface and inner precipitate. 


\section{TICKET Tableaux}

\section{Equilibrium Reaction Tableau}

Table S2 contains a sample TICKET equilibrium reaction tableau. This tableau is formulated in the style of Morel and Hering (7) and works in much the same way as a MINEQL+ (8) tableau. There are, however, a few additions. The TICKET equilibrium reaction tableau separates the formulation of species mass action equations from the formulation of component mass balance equations. At each species-component intersection in the tableau, the first number is the exponent to which the component is raised in the mass action law for the species. The second number is the stoichiometric coefficient of the species in the component mass balance. This flexible scheme is used to implement a simple arsenic-iron surface complexation model.

\begin{tabular}{|c|c|c|c|c|c|c|c|c|c|c|c|c|c|c|}
\hline \multirow[b]{2}{*}{ Species } & \multirow[b]{2}{*}{$K_{\mathrm{f}}$} & \multicolumn{13}{|c|}{ Components } \\
\hline & & As(III) & $\mathrm{As}(\mathrm{IV})$ & $\operatorname{As}(\mathrm{V})$ & $\mathrm{Fe}^{2+}$ & $\mathrm{Fe}^{3+}$ & $\mathrm{Fe}(\mathrm{IV})$ & precip & iprecip & $\mathrm{O}_{2}$ & $\mathrm{O}_{2} \bullet^{-}$ & $\mathrm{H}_{2} \mathrm{O}_{2}$ & INT-OH & Sand \\
\hline$\overline{\mathrm{As}(\mathrm{III})}$ & 1 & 1,1 & 0,0 & 0,0 & 0,0 & 0,0 & 0,0 & 0,0 & 0,0 & 0,0 & 0,0 & 0,0 & 0,0 & 0,0 \\
\hline $\mathrm{As}(\mathrm{IV})$ & 1 & 0,0 & 1,1 & 0,0 & 0,0 & 0,0 & 0,0 & 0,0 & 0,0 & 0,0 & 0,0 & 0,0 & 0,0 & 0,0 \\
\hline $\mathrm{As}(\mathrm{V})$ & 1 & 0,0 & 0,0 & 1,1 & 0,0 & 0,0 & 0,0 & 0,0 & 0,0 & 0,0 & 0,0 & 0,0 & 0,0 & 0,0 \\
\hline $\mathrm{Fe}^{2+}$ & 1 & 0,0 & 0,0 & 0,0 & 1,1 & 0,0 & 0,0 & 0,0 & 0,0 & 0,0 & 0,0 & 0,0 & 0,0 & 0,0 \\
\hline $\mathrm{Fe}^{3+}$ & 1 & 0,0 & 0,0 & 0,0 & 0,0 & 1,1 & 0,0 & 0,0 & 0,0 & 0,0 & 0,0 & 0,0 & 0,0 & 0,0 \\
\hline $\mathrm{Fe}(\mathrm{IV})$ & 1 & 0,0 & 0,0 & 0,0 & 0,0 & 0,0 & 1,1 & 0,0 & 0,0 & 0,0 & 0,0 & 0,0 & 0,0 & 0,0 \\
\hline precip & 1 & 0,0 & 0,0 & 0,0 & 0,0 & 0,0 & 0 & 1,1 & 0,0 & 0,0 & 0,0 & 0,0 & 0,0 & 0,0 \\
\hline iprecip & 1 & 0,0 & 0,0 & 0,0 & 0,0 & 0,0 & 0,0 & 0,0 & 1,1 & 0,0 & 0,0 & 0,0 & 0,0 & 0,0 \\
\hline $\mathrm{O}_{2}$ & 1 & 0,0 & 0,0 & 0,0 & 0,0 & 0,0 & 0,0 & 0,0 & 0,0 & 1,1 & 0,0 & 0,0 & 0,0 & 0,0 \\
\hline $\mathrm{O}_{2} \bullet^{-}$ & 1 & 0,0 & 0,0 & 0,0 & 0,0 & 0,0 & 0,0 & 0,0 & 0,0 & 0,0 & 1,1 & 0,0 & 0,0 & 0,0 \\
\hline $\mathrm{H}_{2} \mathrm{O}_{2}$ & 1 & 0,0 & 0,0 & 0,0 & 0,0 & 0,0 & 0,0 & 0,0 & 0,0 & 0,0 & 0,0 & 1,1 & 0,0 & 0,0 \\
\hline INT-OH & 1 & 0,0 & 0,0 & 0,0 & 0,0 & 0,0 & 0,0 & 0,0 & 0,0 & 0,0 & 0,0 & 0,0 & 1,1 & 0,0 \\
\hline Sand & 1 & 0,0 & 0,0 & 0,0 & 0,0 & 0,0 & 0,0 & 0,0 & 0,0 & 0,0 & 0,0 & 0,0 & 0,0 & 1,1 \\
\hline $\mathrm{FeOH}^{+}$ & $6.17 \times 10^{-2}$ & 0,0 & 0,0 & 0,0 & 1,1 & 0,0 & 0,0 & 0,0 & 0,0 & 0,0 & 0,0 & 0,0 & 0,0 & 0,0 \\
\hline $\mathrm{FeOH}^{2+}$ & $1.00 \times 10^{6}$ & 0,0 & 0,0 & 0,0 & 0,0 & 1,1 & 0,0 & 0,0 & 0,0 & 0,0 & 0,0 & 0,0 & 0,0 & 0,0 \\
\hline $\mathrm{Fe}(\mathrm{OH})_{2}{ }^{+}$ & $5.01 \times 10^{10}$ & 0,0 & 0,0 & 0,0 & 0,0 & 1,1 & 0,0 & 0,0 & 0,0 & 0,0 & 0,0 & 0,0 & 0,0 & 0,0 \\
\hline $\mathrm{Fe}(\mathrm{OH})_{3}{ }^{0}$ & $1.26 \times 10^{11}$ & 0,0 & 0,0 & 0,0 & 0,0 & 1,1 & 0,0 & 0,0 & 0,0 & 0,0 & 0,0 & 0,0 & 0,0 & 0,0 \\
\hline INT & $8.71 \times 10^{-4}$ & 0,0 & 0,0 & 0,0 & 0,0 & 0,0 & 0,0 & 0,0 & 0,0 & 0,0 & 0,0 & 0,0 & 1,1 & 0,0 \\
\hline As(III)-iprecip & $3.70 \times 10^{4}$ & 1,1 & 0,0 & 0,0 & 0,0 & 0,0 & 0,0 & 0,0 & $1,7.85$ & 0,0 & 0,0 & 0,0 & 0,0 & 0,0 \\
\hline As(V)-iprecip & $1.40 \times 10^{5}$ & 0,0 & 0,0 & 1,1 & 0,0 & 0,0 & 0,0 & 0,0 & $1,23.5$ & 0,0 & 0,0 & 0,0 & 0,0 & 0,0 \\
\hline As(III)-Sand & $1.35 \times 10^{-3}$ & 1,1 & 0,0 & 0,0 & 0,0 & 0,0 & 0,0 & 0,0 & 0,0 & 0,0 & 0,0 & 0,0 & 0,0 & 1,1 \\
\hline Fe-Sand & $3.20 \times 10^{-2}$ & 0,0 & 0,0 & 0,0 & 1,1 & 0,0 & 0,0 & 0,0 & 0,0 & 0,0 & 0,0 & 0,0 & 0,0 & 1,1 \\
\hline
\end{tabular}

Since, in the present work, TICKET is used to model systems with fixed $\mathrm{pH}$, there is no need to include the hydrogen ion explicitly as a component in the tableau. It is included implicitly using apparent formation constants for $\mathrm{pH}$-dependent equilibria. For example, the formation reaction and equilibrium constant from Hug and Leupin (1) for $\mathrm{FeOH}^{+}$are: 


$$
\mathrm{Fe}^{2+}+\mathrm{H}_{2} \mathrm{O} \leftrightarrow \mathrm{FeOH}^{+}+\mathrm{H}^{+} \quad \log K_{\mathrm{f}}=-9.51
$$

The mass action expression for this reaction is:

$$
K_{\mathrm{f}}=10^{\log K_{\mathrm{f}}}=\frac{\left[\mathrm{FeOH}^{+}\right]\left[\mathrm{H}^{+}\right]}{\left[\mathrm{Fe}^{2+}\right]}=\frac{\left[\mathrm{FeOH}^{+}\right] 10^{-\mathrm{pH}}}{\left[\mathrm{Fe}^{2+}\right]}
$$

or

$$
K_{\mathrm{f}}=10^{\log K_{\mathrm{f}}+\mathrm{pH}}=\frac{\left[\mathrm{FeOH}^{+}\right]}{\left[\mathrm{Fe}^{2+}\right]}
$$

for a fixed $\mathrm{pH}$. Thus, for the $\mathrm{FeOH}^{+}$species in the equilibrium tableau (Table $\mathrm{S} 2$ ), the $K_{\mathrm{f}}$ value $\left(6.17 \times 10^{-2}\right)$ is obtained from the $\log K_{\mathrm{f}}$ listed above and a $\mathrm{pH}$ of 8.3 (i.e. that used in the experiments).

\section{Kinetic Reaction Tableau}

Table S3 contains a sample TICKET kinetic reaction tableau. Again, a double-indexing scheme is used. The first number at each species-component intersection in the kinetic reaction tableau is the exponent to which the particular component is raised in the rate law for the kinetic reaction. The second number is the stoichiometric coefficient of the component in the kinetic reaction (a positive number denotes consumption; a negative denotes production). Note, as 
indicated in Hug and Leupin (1), species in italics are written to balance the equations but are not included in the model.

\begin{tabular}{|c|c|c|c|c|c|c|c|c|c|c|c|c|c|c|}
\hline \multicolumn{15}{|c|}{ Components } \\
\hline Reaction & $k, \mathrm{M}^{-1} \mathrm{~d}^{-1}$ or $\mathrm{d}^{-1}$ & As(III) & $\mathrm{As}(\mathrm{IV})$ & $\mathrm{As}(\mathrm{V})$ & $\mathrm{Fe}^{2+}$ & $\mathrm{Fe}^{3+}$ & $\mathrm{Fe}(\mathrm{IV})$ & precip & iprecip & $\mathrm{O}_{2}$ & $\mathrm{O}_{2}{ }^{-}$ & $\mathrm{H}_{2} \mathrm{O}_{2}$ & INT-OH & Sand \\
\hline$\overline{\mathrm{As}(\mathrm{IV})+\mathrm{O}_{2} \rightarrow \mathrm{As}(\mathrm{V})+\mathrm{O}_{2}{ }^{\circ}}$ & $9.50 \times 10^{13}$ & 0,0 & 1,1 & $0,-1$ & 0,0 & 0,0 & 0,0 & 0,0 & 0,0 & 1,1 & $0,-1$ & 0,0 & 0,0 & 0,0 \\
\hline $\mathrm{Fe}^{2+}+\mathrm{O}_{2} \rightarrow \mathrm{Fe}^{3+}+\mathrm{O}_{2}$ & $4.67 \times 10^{7}$ & 0,0 & 0,0 & 0,0 & 1,1 & $0,-1$ & 0,0 & 0,0 & 0,0 & 1,1 & $0,-1$ & 0,0 & 0,0 & 0,0 \\
\hline $\mathrm{Fe}^{2+}+\mathrm{O}_{2}{ }^{-}+2 \mathrm{H}^{+} \rightarrow \mathrm{Fe}^{3+}+\mathrm{H}_{2} \mathrm{O}_{2}$ & $8.64 \times 10^{11}$ & 0,0 & 0,0 & 0,0 & 1,1 & $0,-1$ & 0,0 & 0,0 & 0,0 & 00 & 1,1 & $0,-1$ & 0,0 & 0,0 \\
\hline $\mathrm{Fe}^{2+}+\mathrm{H}_{2} \mathrm{O}_{2} \rightarrow \mathrm{INT}$ & $2.33 \times 10^{6}$ & 0,0 & 0,0 & 0,0 & 1,1 & 0,0 & 0,0 & 0,0 & 0,0 & 00 & 00 & 1,1 & $0,-1$ & 0,0 \\
\hline $\mathrm{FeOH}^{+}+\mathrm{H}_{2} \mathrm{O}_{2} \rightarrow$ INT-OH & $7.02 \times 10^{10}$ & 0,0 & 0,0 & 0,0 & 1,1 & 0,0 & 0,0 & 0,0 & 0,0 & 00 & 00 & 1,1 & $0,-1$ & 0,0 \\
\hline INT-OH $\rightarrow$ Fe(IV) & $8.64 \times 10^{10}$ & 0,0 & 0,0 & 0,0 & 0,0 & 0,0 & $0-1$ & 0,0 & 0,0 & 0,0 & 0,0 & 0,0 & 1,1 & 0,0 \\
\hline $\mathrm{Fe}(\mathrm{IV})+\mathrm{Fe}^{2+} \rightarrow \mathrm{Fe}^{3+}+\mathrm{Fe}^{3+}$ & $1.65 \times 10^{8}$ & 0,0 & 0,0 & 0,0 & 1,1 & $0,-2$ & 11 & 0,0 & 0,0 & 0,0 & 0,0 & 0,0 & 0,0 & 0,0 \\
\hline $\mathrm{Fe}(\mathrm{IV})+\mathrm{FeOH}^{+} \rightarrow \mathrm{Fe}^{3+}+\mathrm{Fe}^{3+}$ & $7.19 \times 10^{11}$ & 0,0 & 0,0 & 0,0 & 1,1 & $0,-2$ & 11 & 0,0 & 0,0 & 0,0 & 0,0 & 0,0 & 0,0 & 0,0 \\
\hline $\mathrm{As}(\mathrm{III})+\mathrm{Fe}(\mathrm{IV}) \rightarrow \mathrm{As}(\mathrm{IV})+\mathrm{Fe}^{3+}$ & $3.60 \times 10^{10}$ & 1,1 & $0,-1$ & 0,0 & 0,0 & $0,-1$ & 11 & 0,0 & 0,0 & 0,0 & 0,0 & 0,0 & 0,0 & 0,0 \\
\hline $\mathrm{Fe}^{3+}+\mathrm{O}_{2} \bullet^{\bullet} \rightarrow \mathrm{Fe}^{2+}+\mathrm{O}_{2}$ & $1.30 \times 10^{13}$ & 0,0 & 0,0 & 0,0 & $0,-1$ & 1,1 & 0,0 & 0,0 & 0,0 & $0,-1$ & 1,1 & 0,0 & 0,0 & 0,0 \\
\hline $\mathrm{FeOH}^{2+}+\mathrm{O}_{2} \cdot \rightarrow \mathrm{Fe}^{2+}+\mathrm{O}_{2}+\mathrm{OH}$ & $1.30 \times 10^{19}$ & 0,0 & 0,0 & 0,0 & $0,-1$ & 1,1 & 0,0 & 0,0 & 0,0 & $0,-1$ & 1,1 & 0,0 & 0,0 & 0,0 \\
\hline $\mathrm{Fe}(\mathrm{OH})_{2}^{+}+\mathrm{O}_{2}{ }^{-} \rightarrow \mathrm{Fe}^{2+}+\mathrm{O}_{2}+2 \mathrm{OH}$ & $6.50 \times 10^{23}$ & 0,0 & 0,0 & 0,0 & $0,-1$ & 1,1 & 0,0 & 0,0 & 0,0 & $0,-1$ & 1,1 & 0,0 & 0,0 & 0,0 \\
\hline $\mathrm{Fe}(\mathrm{OH})_{3}{ }^{0}+\mathrm{Fe}(\mathrm{OH})_{3}{ }^{0} \rightarrow$ precip + iprecip & $2.67 \times 10^{35}$ & 0,0 & 0,0 & 0,0 & 0,0 & 22 & 0,0 & $0,-1$ & $0,-1$ & 0,0 & 0,0 & 0,0 & 0,0 & 0,0 \\
\hline $\mathrm{Fe}(\mathrm{OH})_{3}{ }^{0}+$ precip $\rightarrow$ precip + iprecip & $2.12 \times 10^{24}$ & 0,0 & 0,0 & 0,0 & 0,0 & 1,1 & 0,0 & 1,0 & $0,-1$ & 0,0 & 0,0 & 0,0 & 0,0 & 0,0 \\
\hline
\end{tabular}

Reactions involved hydrolyzed forms of $\mathrm{Fe}(\mathrm{II})$ and $\mathrm{Fe}(\mathrm{III})$ are written in terms of the components $\mathrm{Fe}^{2+}$ and $\mathrm{Fe}^{3+}$ with apparent rate constants corrected for $\mathrm{pH}$. Consider the reaction of $\mathrm{FeOH}^{2+}$ with superoxide with the second order kinetic rate constant from Hug and Leupin (1):

$$
\mathrm{FeOH}^{2+}+\mathrm{O}_{2} \bullet^{-} \rightarrow \mathrm{Fe}^{2+}+\mathrm{O}_{2}+\mathrm{OH}^{-} \quad k=1.30 \times 10^{13} \mathrm{M}^{-1} \mathrm{~d}^{-1}
$$

If the reaction is considered to be elementary, the following rate expression results:

$$
\text { Rate }=k\left[\mathrm{FeOH}^{2+}\right]^{1}\left[\mathrm{O}_{2}^{\bullet^{-}}\right]^{1}
$$

From the equilibrium reaction tableau (Table S2), the mass action expression for $\left[\mathrm{FeOH}^{2+}\right]$ is

$$
\left[\mathrm{FeOH}^{2+}\right]=K_{\mathrm{f}}\left[\mathrm{Fe}^{3+}\right] \quad K_{\mathrm{f}}=1.00 \times 10^{6}
$$


where $K_{\mathrm{f}}$ is the apparent equilibrium constant at $\mathrm{pH}$ 8.3. Substituting the expression for $\left[\mathrm{FeOH}^{2+}\right]$ in equation $\mathrm{S} 3$ into equation $\mathrm{S} 2$, the following rate expression is obtained:

$$
\text { Rate }=k^{\prime}\left[\mathrm{Fe}^{3+}\right]^{1}\left[\mathrm{O}_{2^{\bullet}}\right]^{1} \quad \text { where } k^{\prime}=k \cdot K_{\mathrm{f}}
$$

Following from this expression, the rate expression for the kinetic reaction of $\mathrm{FeOH}^{2+}$ with superoxide is formulated in the tableau (Table S3) with the $\mathrm{Fe}^{3+}$ and $\mathrm{O}_{2}{ }^{\bullet^{-}}$components raised to the first power and a rate constant defined as the product of the intrinsic rate constant and the apparent equilibrium constant at $\mathrm{pH}=8.3$. The components $\mathrm{Fe}^{3+}$ and $\mathrm{O}_{2} \bullet^{-}$are consumed while $\mathrm{Fe}^{2+}$ and $\mathrm{O}_{2}$ are produced.

\section{TICKET Arsenic-Iron(III) Oxide Adsorption Model}

Iron surface complexation models envision the binding of dissolved chemical species to available sites on the surface of solid ferric (hydr)oxides. The maximum binding capacity of a site type — the site density—can be expressed as a mole fraction (mol As/mol Fe). For systems where the total amount of $\mathrm{Fe}(\mathrm{III})$ is constant, the site densities and total $\mathrm{Fe}$ (III) component concentration are used to determine the total concentration for the site components.

Following the above paradigm, the concentration of $\mathrm{Fe}(\mathrm{III})$ solid is best represented in TICKET by the component "iprecip" (Tables S2 and S3) since in the oxic layer its concentration is far greater than "precip" in all model runs. The concentration of "iprecip" is constantly changing as dissolved Fe(III) produced by oxidation precipitates. The TICKET program lacks the ability to maintain the total concentration of a site component as some fixed fraction of the 
total concentration of the $\mathrm{Fe}(\mathrm{III})$ solid component as the latter changes in time. Rather than revise the TICKET code, the following method is employed.

Consider the following TICKET equilibrium reaction tableau with two components forming three species. We wish to have arsenic "As" form a surface complex with a site on "iprecip" whose concentration is some fixed fraction of the total "iprecip" concentration. To do this, the double-indexing scheme in the equilibrium tableau is utilized.

\begin{tabular}{|l|c|c|l|}
\cline { 2 - 4 } \multicolumn{1}{c|}{} & As & iprecip & $K_{\mathrm{f}}$ \\
\hline As & 1,1 & 0,0 & $K_{\mathrm{f}, \text { As }}$ \\
\hline iprecip & 0,0 & 1,1 & $K_{\text {f,iprec }}$ \\
\hline As $=$ iprecip & 1,1 & $1, \alpha$ & $K_{\text {f,As }=\text { iprecip }}$ \\
\hline
\end{tabular}

The above tableau sets up three mass action equations. The equations for the first two species define them as equal to the component concentrations (the formation constants are both 1 by definition). The equation for the third species is:

$$
K_{\mathrm{f}, \mathrm{As} \equiv \text { iprecip }}=\frac{[\text { As } \equiv \text { iprecip }]}{[\text { As }][\text { iprecip }]}
$$

The tableau also sets up two mass balance equations:

$$
\begin{aligned}
& \mathrm{As}_{\mathrm{T}}=[\mathrm{As}]+K_{\mathrm{f}, \mathrm{As}=\text { iprecip }}[\text { As }][\text { iprecip }] \\
& \text { iprecip }_{\mathrm{T}}=[\text { iprecip }]+\alpha K_{\mathrm{f}, \mathrm{As}=\text { iprecip }}[\mathrm{As}][\text { iprecip }]
\end{aligned}
$$

Solving equation S7 for [iprecip] yields: 


$$
\text { [iprecip }]=\frac{\operatorname{iprecip}_{\mathrm{T}}}{1+\alpha K_{\mathrm{f}, \mathrm{As} \equiv \text { iprecip }}[\mathrm{As}]}
$$

From equation $\mathrm{S} 6$, the expression for $[\mathrm{As}]_{\mathrm{ads}}$ is:

$$
[\mathrm{As}]_{\mathrm{ads}}=[\mathrm{As}=\mathrm{iprecip}]=K_{\mathrm{f}, \mathrm{As}=\text { iprecip }}[\mathrm{As}][\text { iprecip }]
$$

The expression for [iprecip] in equation S8 is substituted into equation S9 to obtain the following expression:

$$
[\mathrm{As}]_{\mathrm{ads}}=\frac{K_{\mathrm{f}, \mathrm{As}=\text { iprecip }}[\mathrm{As}] \mathrm{iprecip}_{\mathrm{T}}}{1+\alpha K_{\mathrm{f}, \mathrm{As}=\text { iprecip }}[\mathrm{As}]}
$$

Now let $\alpha K_{\mathrm{f}, \mathrm{As} \equiv \text { iprecip }}[\mathrm{As}]=\beta$. When $[\mathrm{As}]$ is high (i.e. $\beta>>1$ ):

$$
[\mathrm{As}]_{\mathrm{ads}}=\frac{\operatorname{iprecip}_{\mathrm{T}}}{\alpha}
$$

When $[$ As] is low (i.e. $\beta<<1$ ):

$$
[\mathrm{As}]_{\mathrm{ads}}=K_{\mathrm{f}, \mathrm{As}=\text { iprecip }}[\mathrm{As}] \operatorname{iprecip}_{\mathrm{T}}
$$


The right hand side of equation $\mathrm{S} 11$ it is the total site concentration (i.e. it is the total Fe(III) concentration multiplied by a constant $1 / \alpha$ ). It follows that that quantity $1 / \alpha$ represents the site

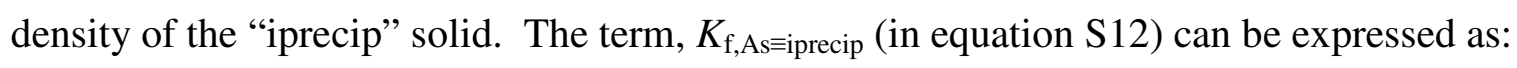

$$
K_{\mathrm{f}, \mathrm{As} \equiv \text { iprecip }}=\frac{K_{\mathrm{f}, \mathrm{As} \equiv \text { site }}}{\alpha}
$$

where $K_{\mathrm{f}, \mathrm{As} \equiv \text { site }}$ is the intrinsic formation constant for arsenic complexation to a site on Fe(III) solid. Substituting equation S13 into equation S12 and replacing the iprecip $\mathrm{T}_{\mathrm{T}} / \alpha$ term with the total site concentration $\left(\mathrm{Site}_{\mathrm{T}}\right)$ in equations $\mathrm{S} 11$ and $\mathrm{S} 12$, we obtain the following more transparent analogs to equations S11 and S12:

$$
\begin{array}{ll}
{[\mathrm{As}]_{\mathrm{ads}}=\text { Site }_{\mathrm{T}}} & \text { (when [As] is high) } \\
{[\mathrm{As}]_{\mathrm{ads}}=K_{\mathrm{f}, \mathrm{As} \equiv \mathrm{Site}}[\mathrm{As}] \mathrm{Site}_{\mathrm{T}} \quad \text { (when [As] is low) }}
\end{array}
$$

To complete this simplified model of arsenic surface complexation to Fe(III) solid, the values of $\alpha$ and $K_{\mathrm{f}, \mathrm{As}=\text { iprecip }}$ for $\mathrm{As}(\mathrm{III})$ and $\mathrm{As}(\mathrm{V})$ are calibrated using the Dixit and Hering (4) surface complexation model, which provides parameters describing the adsorption of arsenic species to hydrous ferric oxide (HFO) (Table S4).

These parameters are readily incorporated into a MINEQL+ surface complexation model (two-layer adsorption) that includes corrections for electrostatic interactions. To calibrate the TICKET arsenic surface complexation scheme, adsorbed arsenic versus soluble arsenic data were computed using MINEQL+. These calculations were performed with two total iron 
concentrations $\left(2.00 \times 10^{-3} \mathrm{M}\right.$ and $\left.2.25 \times 10^{-5} \mathrm{M}\right)$ for the $\mathrm{pH}$ and ionic strength conditions of the column experiment. The higher iron concentration is the maximum total sediment iron concentrations encountered in the experiments while the lower iron value was chosen merely to insure that the TICKET scheme would extrapolate reasonably well to lower Fe(III) solid concentrations. The results are shown in Figure S2 (data points).

\begin{tabular}{|c|c|}
\hline $\begin{array}{l}\text { TABLE S4. Summary of HFO reactions anc } \\
\text { characteristics from Dixit and Hering (4) }\end{array}$ & \\
\hline Reactions & $\log K$ \\
\hline$\equiv \mathrm{FeOH}+\mathrm{H}^{+} \leftrightarrow \mathrm{FeOH}_{2}^{+}$ & 7.29 \\
\hline$\equiv \mathrm{FeOH} \leftrightarrow \mathrm{FeO}^{-}+\mathrm{H}^{+}$ & -8.93 \\
\hline$\equiv \mathrm{FeOH}+\mathrm{AsO}_{4}{ }^{3-}+3 \mathrm{H}^{+} \leftrightarrow \equiv \mathrm{FeH}_{2} \mathrm{AsO}_{4}+\mathrm{H}_{2} \mathrm{O}$ & 29.88 \\
\hline$=\mathrm{FeOH}+\mathrm{AsO}_{4}{ }^{3-}+2 \mathrm{H}^{+} \leftrightarrow \equiv \mathrm{FeHAsO}_{4}{ }^{-}+\mathrm{H}_{2} \mathrm{O}$ & 24.43 \\
\hline$=\mathrm{FeOH}+\mathrm{AsO}_{4}{ }^{3-}+\mathrm{H}^{+} \leftrightarrow \equiv \mathrm{FeAsO}_{4}{ }^{2-}+\mathrm{H}_{2} \mathrm{O}$ & 18.10 \\
\hline$\equiv \mathrm{FeOH}+\mathrm{AsO}_{3}{ }^{3-}+3 \mathrm{H}^{+} \leftrightarrow \equiv \mathrm{FeH}_{2} \mathrm{AsO}_{3}+\mathrm{H}_{2} \mathrm{O}$ & 38.76 \\
\hline$=\mathrm{FeOH}+\mathrm{AsO}_{3}{ }^{3-}+2 \mathrm{H}^{+} \leftrightarrow \equiv \mathrm{FeHAsO}_{3}^{-}+\mathrm{H}_{2} \mathrm{O}$ & 31.87 \\
\hline \multicolumn{2}{|l|}{ HFO Characteristics } \\
\hline Surface area $\left(\mathrm{m}^{2} / \mathrm{g}\right)$ & 600 \\
\hline Formula weight $(\mathrm{g} / \mathrm{mol})$ & 177.7 \\
\hline \multicolumn{2}{|l|}{ Site density (mol As $/ \mathrm{mol} \mathrm{Fe}$ ) for } \\
\hline As(III) & 0.31 \\
\hline $\mathrm{As}(\mathrm{V})$ & 0.24 \\
\hline
\end{tabular}

The values of $\alpha$ and $K_{\mathrm{f}, \mathrm{As}=\text { iprecip }}$ for $\mathrm{As}(\mathrm{III})$ and $\mathrm{As}(\mathrm{V})$ are obtained by a calibration to the MINEQL+ output at both total iron concentrations simultaneously. The resulting TICKET fits are also shown in Figure S2 (lines). The $\alpha$ and $K_{\mathrm{f}, \mathrm{As}=\mathrm{iprecip}}$ for As(III) are $7.85 \mathrm{~mol} \mathrm{Fe} / \mathrm{mol}$ As and $10^{4.57}$, respectively. The $\alpha$ and $K_{\mathrm{f}, \mathrm{As}=\text { iprecip }}$ for $\mathrm{As}(\mathrm{V})$ are $23.5 \mathrm{~mol} \mathrm{Fe} / \mathrm{mol}$ As and $10^{5.15}$, respectively. The fit to the data is very satisfactory. Discrepancies between the MINEQL+ output and the TICKET fit are due to electrostatic interaction effects which the calibrated TICKET reactions could not capture. However, the TICKET reactions provide a reasonable 
approximation of arsenic surface complexation to HFO that is easily incorporated into the column model.
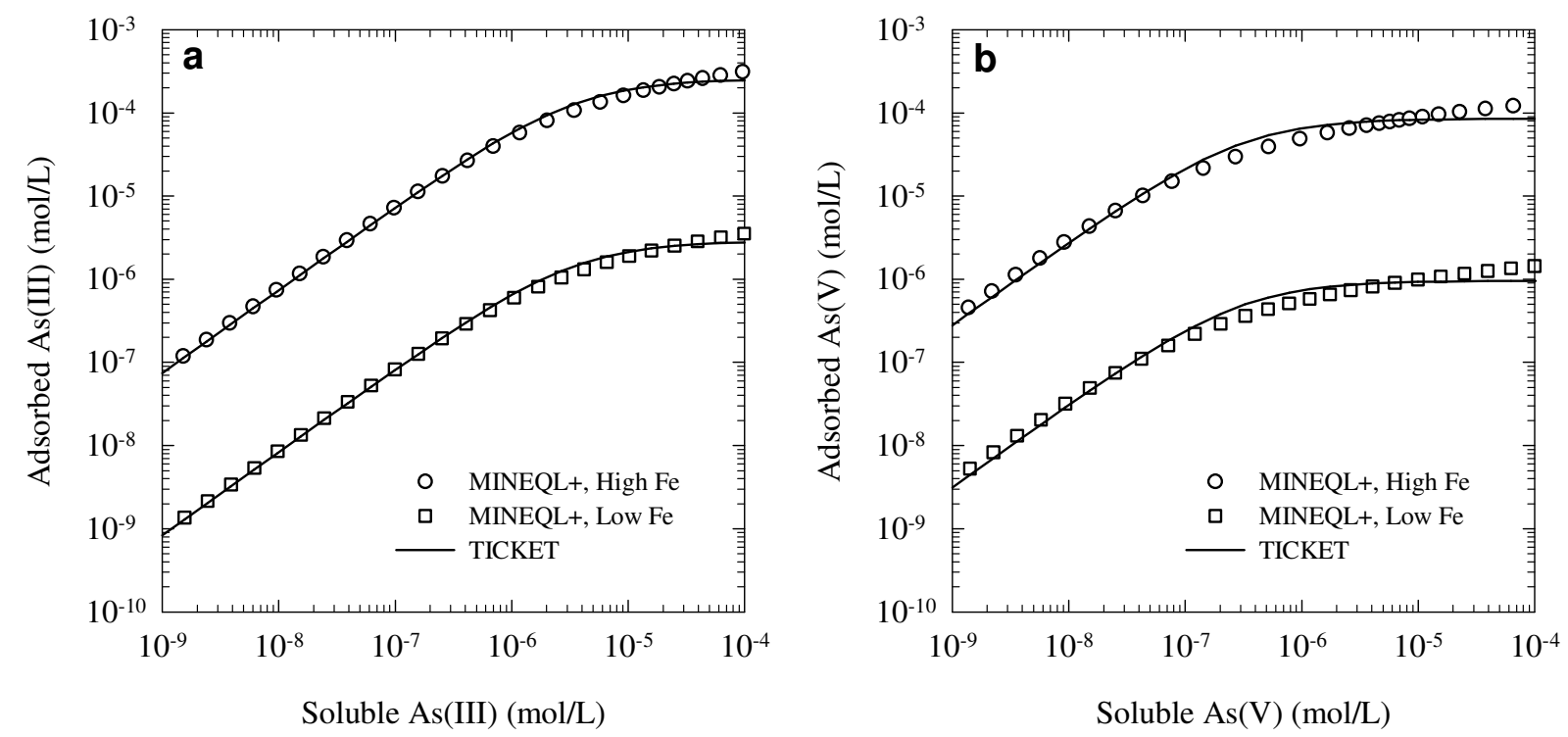

Figure S2. MINEQL+ (8) output and calibrated TICKET output for a) As(III) and b) As(V). High Fe $=2.00 \times 10^{-3}$ $\mathrm{M}(0.178 \mathrm{~g} / \mathrm{L}$ HFO $)$; Low Fe $=2.25 \times 10^{-5} \mathrm{M}(0.002 \mathrm{~g} / \mathrm{L}$ HFO $)$. The TRIS concentration is $0.05 \mathrm{M}$ and the $\mathrm{pH}$ is fixed at 8.30. Ionic strength corrections are calculated by MINEQL+.

\section{Porewater Sampling}

The porewater of the column was sampled using a porewater sampler (Figure S3) based on a design used by Berg and McGlathery (9). A 30-cm stainless steel needle with a syringe attached was used to sample the sediment porewater at each depth (starting at the top of the sediment and proceeding downward). Calculations indicate that a 3-mL sample could be taken with a depth resolution of $1 \mathrm{~cm}$ with minimal disturbance to the surrounding porewater. To minimize disturbance, a sampling rate of approximately $1-\mathrm{mL}$ per minute was used, and the samples were taken in a star-like pattern to maximize the linear distance between each sample and those taken at the two depths above it. 


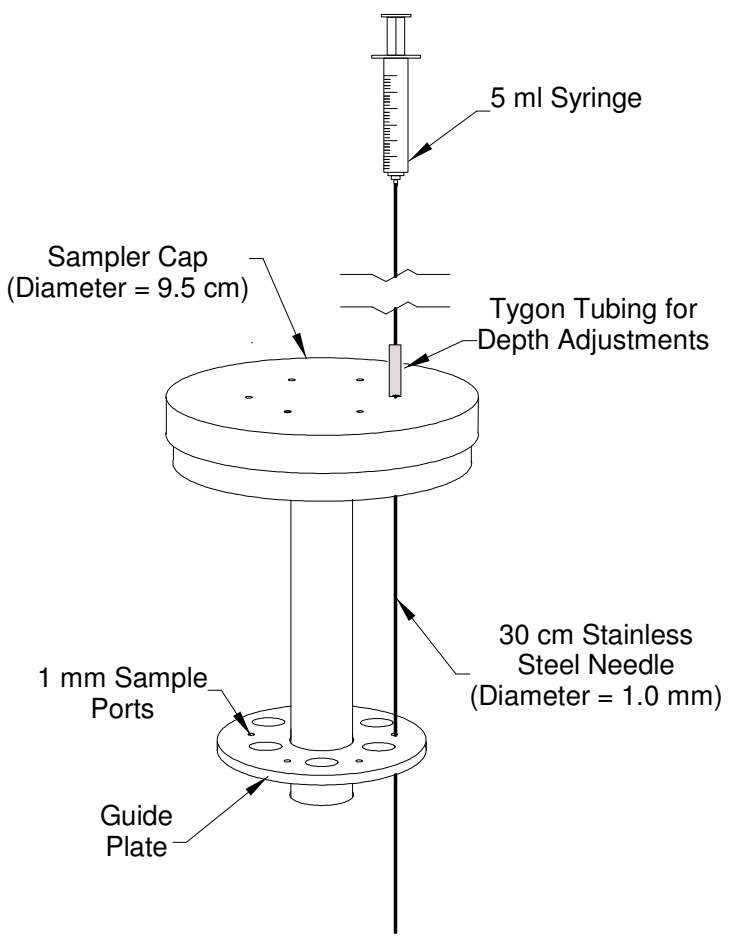

Figure S3. Porewater sampler

\section{Solids Analysis and Acid Extraction.}

Each $0.5-\mathrm{cm}$ interval of the sediment was divided into quarters. One quarter was transferred to a pre-weighed aluminum pan, weighed to determine its wet mass, and placed in an oven at $103^{\circ} \mathrm{C}$. Periodically, each portion was removed, placed in a dessicator for 30 minutes, and weighed until its mass was constant. The difference between the wet and dry masses was used to calculate the solids concentration. The remaining three quarters of each sediment slice were weighed and placed into plastic sample containers containing $25 \mathrm{~mL}$ of $2 \mathrm{M} \mathrm{HCl}$. The containers were capped and left to sit for 48 hours in the dark, and periodically shaken 
vigorously. After the allotted time, the acid extraction was filtered using a $0.1-\mu \mathrm{m}$ Poretics syringe filter, and the filtrate was analyzed for total arsenic and total iron. 


\section{References}

1. Hug, S. J.; Leupin, O. Iron-catalyzed oxidation of arsenic(III) by oxygen and by hydrogen peroxide: $\mathrm{pH}$-dependent formation of oxidants in the Fenton reaction. Environ. Sci. Technol. 2003, 37, 2734-2742.

2. Miller, B. E. Development of a general aquatic multi-component reactive transport computer model, with application to a wetland sediment. Doctoral thesis, Clemson University, 1997.

3. Parkhurst, D. L.; Appelo, C. A. J. User's guide to PHREEQC (Version2)—A computer program for speciation, batch-reaction, one-dimensional transport, and inverse geochemical calculations: U. S. Geological Survey Water-Resources Investigations Report 99-4259, 1999

4. Dixit, S.; Hering, J. G. Comparison of $\operatorname{arsenic}(\mathrm{V})$ and $\operatorname{arsenic(III)~sorption~onto~iron~oxide~}$ minerals: implications for arsenic mobility. Environ. Sci. Technol. 2003, 37, 4182-4189.

5. Dzombak, D. A.; Morel, F. M. M. Surface Complexation Modeling: Hydrous Ferric Oxide; John Wiley\&Sons: New York, 1990.

6. Millero, F. J.; Sotolongo, S.; Izaguirre, M. The oxidation kinetics of $\mathrm{Fe}(\mathrm{II})$ in seawater. Geochim. Cosmochim. Acta. 1987, 51, 793-801.

7. Morel, F. M. M.; Hering, J. G. Principles and Applications of Aquatic Chemistry; John Wiley \& Sons: New York, 1993.

8. Schecher, W. D.; McAvoy, D. C. MINEQL+: A chemical equilibrium modeling system, Version 4.0 for Windows; Environmental Research Software: Hallowell, ME, 1998.

9. Berg, P.; McGlathery, K. J. A high-resolution pore water sampler for sandy sediments. Limnol. Oceanogr. 2001, 46, 203-210. 